
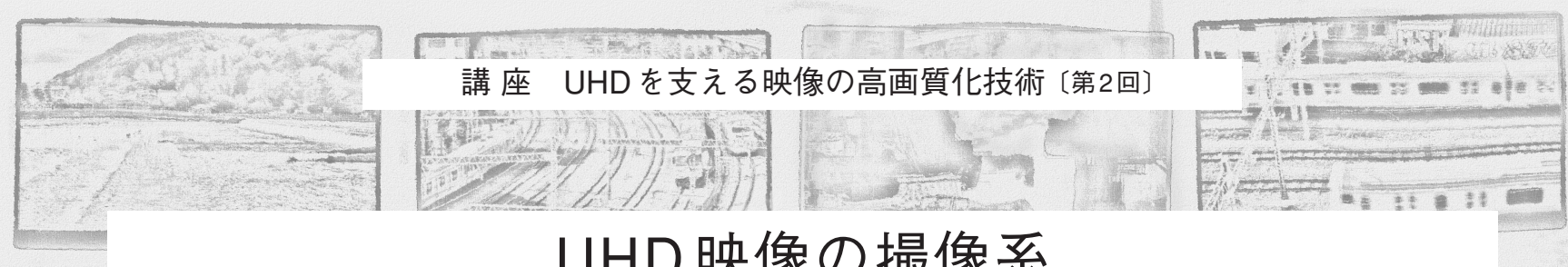

\title{
UHD 映像の撮像系
}
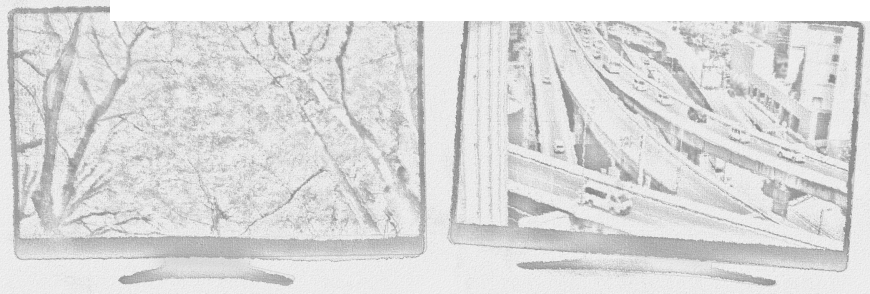

\section{1. まえがき}

UHD 映像は従来の映像フォーマットの仕様を大きく拡張 し, 今までに経験したことのない臨場感ある視聴体験がで きる映像システムを目的としたものである。そのパラメー 夕は, 人間科学的研究をべースにして空間解像度だけでな く, 色再現範囲, 明るさの再現範囲, 各画素の階調特性, 時間解像度について改善が図られている。

本稿では, 具体的にこれらの性能を実現するUHD映像用 カメラの開発経過を振り返るとともに, 高画質化に向けて 開発・導入された特徵的な技術を解説する.

\section{2. カメラの開発経過}

筆者らはUHD 映像の中でも最上位フォーマットとなる 8K システムの前身として，2002年に初めて 4000 本級映像 システムを提案し, カメラ, およびプロジェクタを展示し た ${ }^{1)}$. 当時のシステムはカメラヘッド $80 \mathrm{~kg}$, 収録装置 $200 \mathrm{~kg}$ という大掛かりなものであり, 屋外ロケではカメラヘッド を運ぶのに車両を用意したこともあった．当然のことなが ら, ハイビジョンカメラのような機動性ある運用は実現で きないだろうと思われた。しかし，2015年には撮像，収録 部を合わせてもわずか約 $7 \mathrm{~kg}$ のカムコーダが実用化され， カメラマン 1 人による撮影が可能になった(図1).

この例に見るように，この 10 年余でUHDに係る撮像技 術は大きく進歩した. 図 2 に主な放送・映画用 $4 \mathrm{~K}, 8 \mathrm{~K}$ 力 メラの試作開発時期，または実用化時期をプロットした.

2000 ラインの走査線を持つ $4 \mathrm{~K}$ カメラは，1995年頃から撮 像実験が行われた ${ }^{2)}$ が，実用的なものが開発されるようにな るのは 2000 年代中頃からである. ディジタルシネマの普及 とともに, 映画制作用のフィルムカメラの置き換えとして, 単板カラーカメラを中心に開発が進められた. 2000年代の後 半には光学系フォーマットとしてスーパー $35 \mathrm{~mm}$ (以下, S35 mm と記す) を採用したカメラが各社から発表，または

\footnotetext{
$\dagger$ NHK 放送技術研究所

"Picture Quality Enhancement Technologies Supporting UHD (2); New Features in UHD Cameras for Enhancing Image Quality" by Kohji Mitani (NHK Science \& Technology Research Laboratories, Tokyo)
}

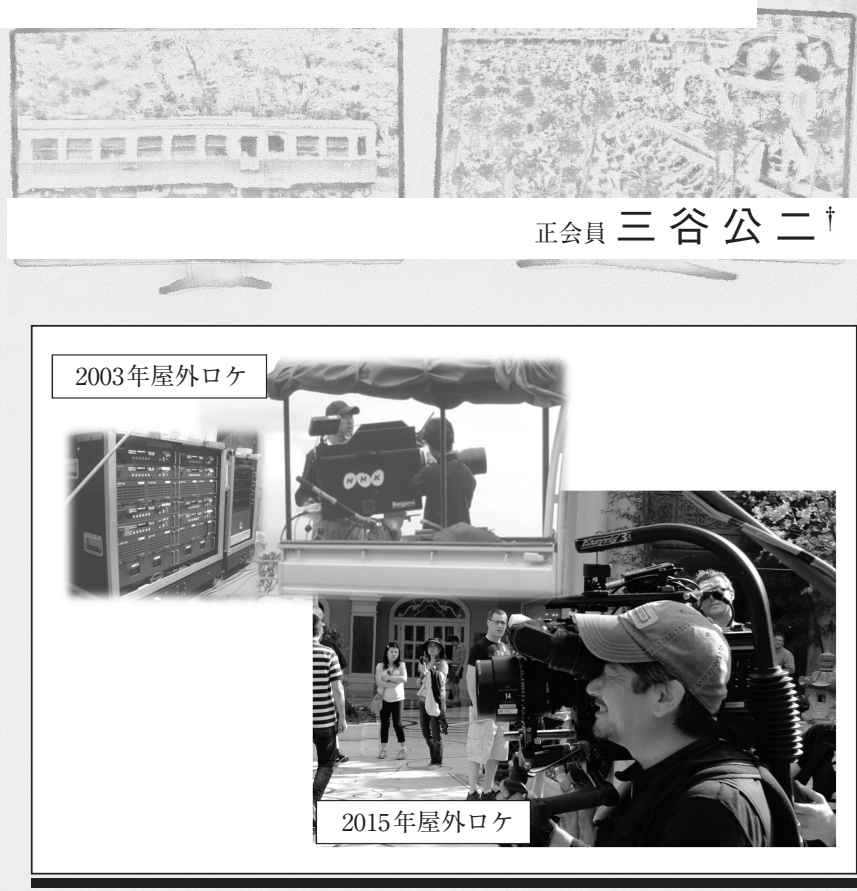

図1 8K撮影収録システムの進化

発売され, 本格的な実用化の時期を迎えた. さらにテレビ ジョン用フォーマット (UHDTV) として $4 \mathrm{~K}, 8 \mathrm{~K}$ フォーマッ トが国際規格として承認され3)，スポーツや劇場のライブ中 継などもハイビジョンと同様の制作環境が求められるよう になると，2014年以降には $2 / 3$ 型の色分解プリズムを用いる $4 \mathrm{~K}$ カラも開発，実用化された.

$8 \mathrm{~K}$ カメラ, テレビジョン用カメラとして開発が進めら れたが，1枚では充分な解像度を得られる撮像素子が開発 されておらず，そのため撮像素子を複数枚用いることに よって高解像度を眓った.このことから, 当初よりプリズ ム撮像方式を用いたカメラの開発が進められた。 その後, 2007 年に初めて動画用 3,300 万画素の撮像素子が開発され る4) と, 単板方式の $8 \mathrm{~K}$ カメのの開発も進められるようにな り，2015年には S35 mm 光学系を採用した実用的なカメラ が複数のメーカから発表された.

現在, 放送用の $4 \mathrm{~K}, 8 \mathrm{~K}$ 単板カメラとしては, S35 mm 光 学系を採用したものが主流であるが， $4 / 3$ 型や $2 / 3$ 型光学系 を採用した小型化も進んできた. プリズム撮像方式のカメラ は, $4 \mathrm{~K}$ では $2 / 3$ 型光学系, $8 \mathrm{~K}$ では 1.25 型光学系のものが用 いられている.これらの光学系に関するカメラ・レンズ機器 の相互接続に関しては，ARIBの技術資料TR-B375)に詳細が 規定されている. 


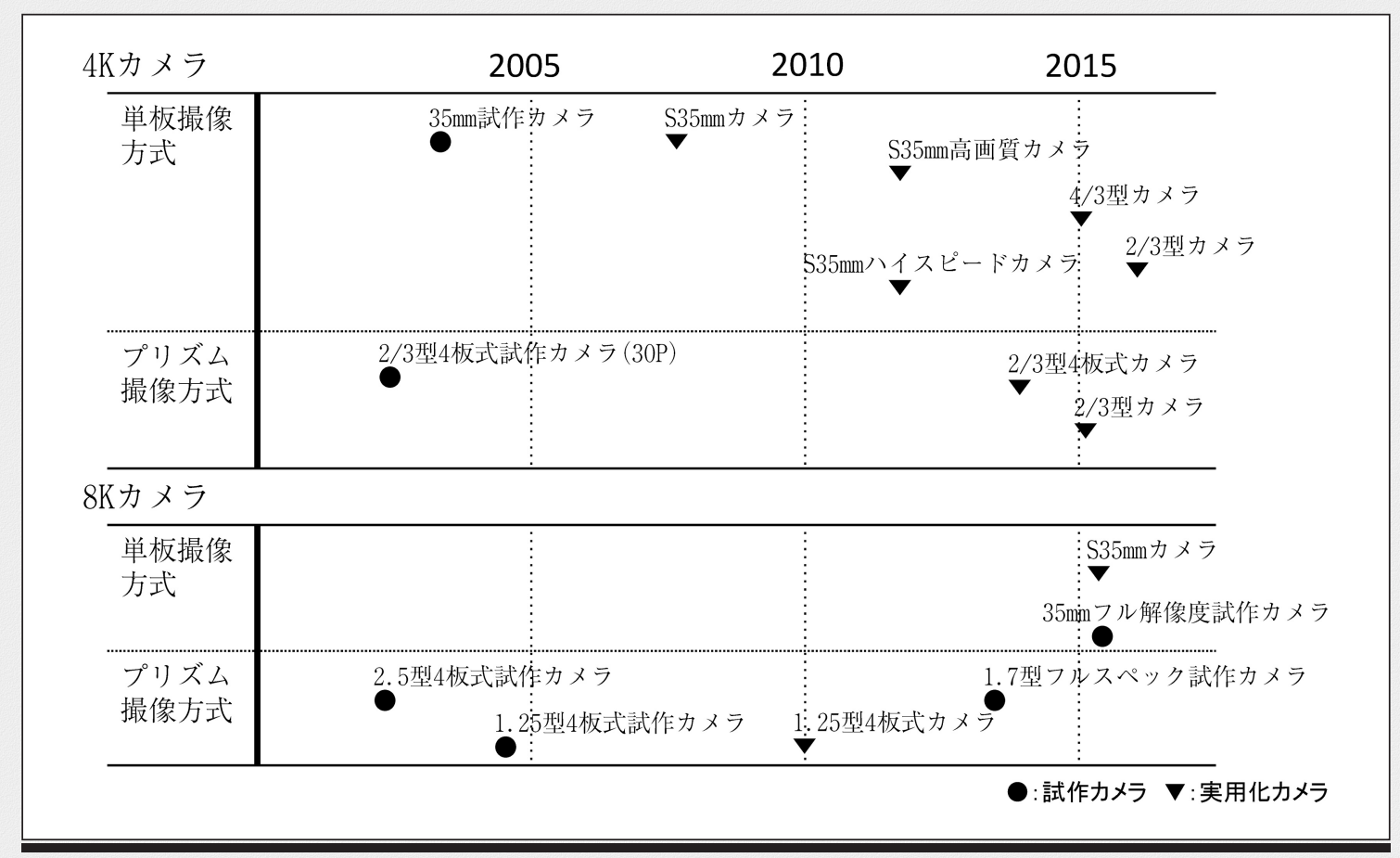

図2 主なUHDカメラの試作, 実用化時期

次章ではこれらのUHD用カメラの特徴的な技術につい て解説する.

\section{3. 高解像度, 高フレームレート化に係る技術}

\section{1 光学系の解像度特性}

高精細な映像を撮影するためには撮像素子の多画素化と ともに，それに見合った解像度特性を有する光学系が求め られる。一方で, 実用的なカメラ開発には機動性や運用性 を考慮する必要があり, 自ずと光学系のサイズにも制約が 生じる.

図3は光学系の収差や歪みを無視した理想的なレンズの各 光学系サイズにおける光学像の変調伝達関数 (Modulation Transfer Function, 以下, MTFと記す) を示す. 加えて, $2 / 3$ 型ハイビジョンカメラに用いられる光学系の特性例も 併せて記載した。限界解像周波数における光学系の MTF として, ハイビジョンカメラとほぼ同じ $50 \%$ 程度の応答を 得ようとすると, $8 \mathrm{~K}$ カメラでは 1.25 型以上の光学系が必要

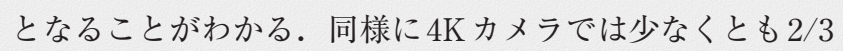
型光学系が必要となる. したがって, 図2のカメラ開発年 表からわかるように, 光学系で充分な解像度を得るために, UHDの撮像系, 特に $8 \mathrm{~K}$ カメラでは, S35 mm 1.25 型な どハイビジョンに比べ大型の光学系を採用している.

ここまでの検討は理想的な光学系を前提とした場合であ る. 実際の光学系では収差や歪み, 製造上の誤差などによ り, 光学系の解像度が劣化するが, UHD用カメラでは, それらの解像度劣化をできるだけ補償するような信号処理 機能が設けられている. その一つがレンズの倍率色収差を 補正する機能である.

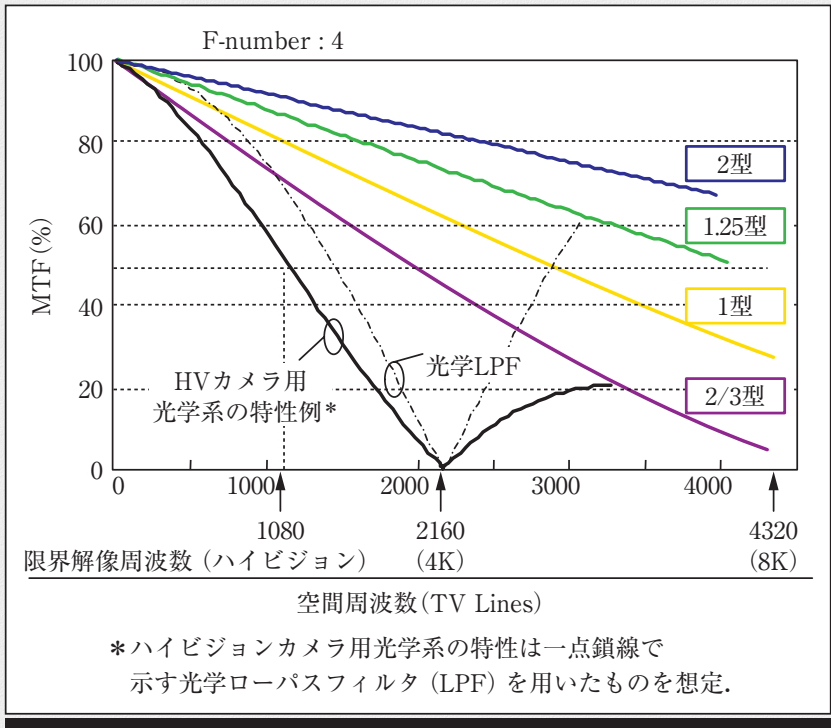

図3理想レンズの解像度特性

倍率色収差は, レンズの屈折率が赤, 緑, 青の光によっ て異なるために生じる光学像の色ずれである. それはレ ンズの光軸から離れるほど，つまり画面の中央部から周 辺部に行くほど大きくなる．また，レンズのズーム倍率 や絞り，焦点距離によっても変化する。そこで多くの UHD用カメラには, 高精度な補正を実時間で行うために, レンズ個々の補正データを自動的に読み达み, そのデー 夕に応じて補正する機能が設けられている6). その処理回 路の一例を図4に示す.

その他にも, 画面の中央部と周辺部で輪郭強調処理のパ ラメータを変更するなど，適応的な処理を実現しているも 


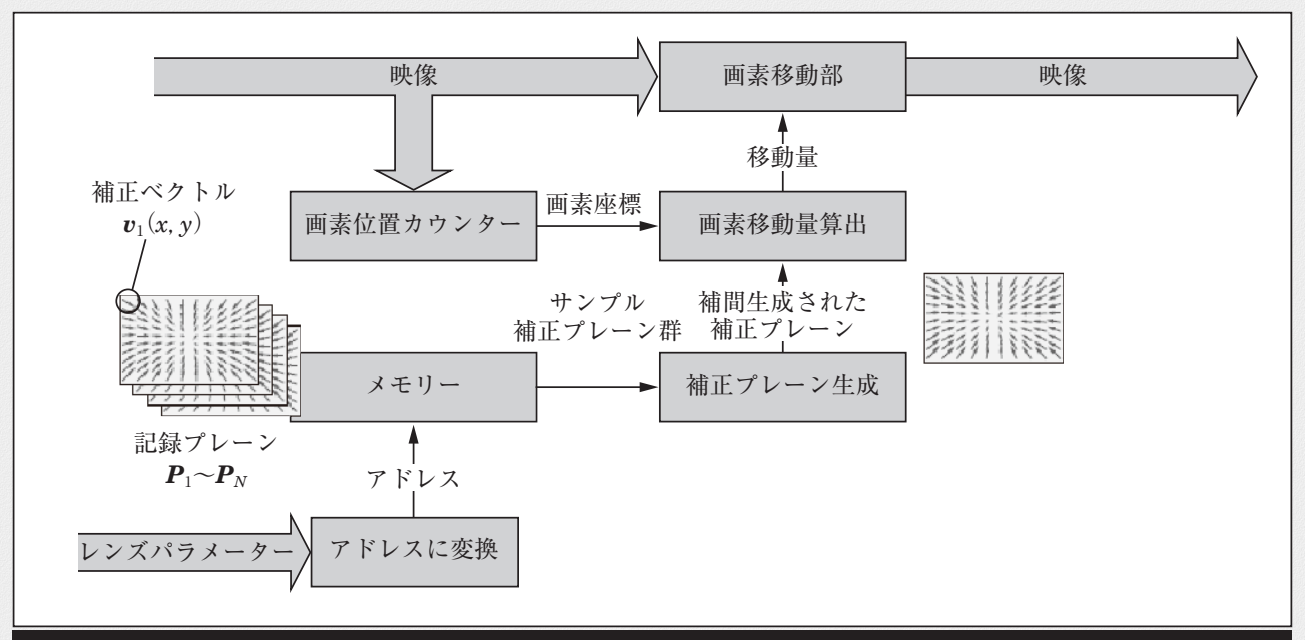

図4倍率色収差補正機能

のもあり, 今後も光学系の特性と密接に関連した高度な信 号処理が開発・導入されるものと思われる.

\section{2 撮像素子の性能向上}

UHD カメラ用撮像素子の開発には画素サイズの微細化と ともに, 感度, ダイナミックレンジなどの高性能化が求め られる. 図5は，1996年以降に当会情報センシング研究会に

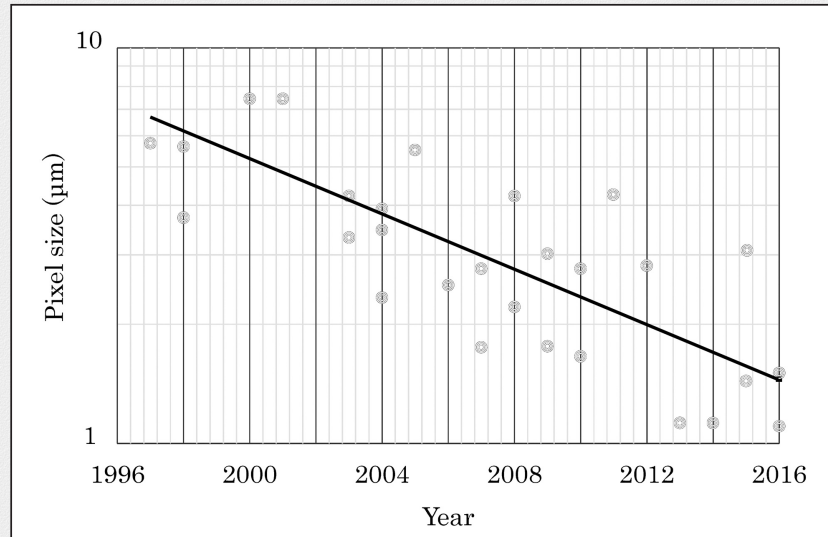

(a) 画素サイズ

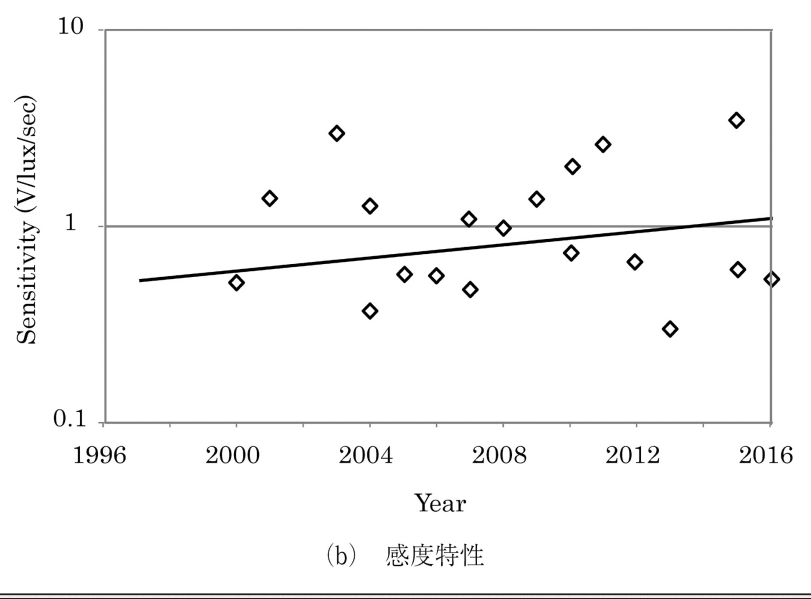

図 5 画素サイズと感度特性の変遷
報告された，固体撮像素子の画素サイズと感度特性をプ ロットしたものである。これを見ると，画素サイズはこの 20 年で約 $1 / 5 \sim 1 / 7$ 程度まで縮小し， $1 \mu \mathrm{m}$ 角程度の画素まで 製造できるようになったことがわかる(眓5 (a)).

画素の微細化と併行して, 撮像性能を向上するための検 討も進められている.すでに一部の回路を複数画素で共有 する画素共有型レイアウト技術や，光導波路構造，裏面照 射型の画素構造などの技術が実用化されている. その結果， 画素サイズの微細化が進んだにもかかわらず，感度特性は 図 5 (b) に示すようにほぼ一定，もしくはさらなる高感度 化を実現している.

高感度化の一方法である裏面照射型の画素構造を図 6 7) に示す．光が入射する側にフォトダイオードを作り，信号 読出し回路をその下に形成することにより，ほぼ100\%の 開口率を実現している. 加えて，信号読出し回路の設計や 配線の自由度が増し, 光電変換により生成された電荷を確 実に捕獲できることから, 感度や飽和電荷数などの撮像性 能が大きく向上している.

このような最先端の技術を用いた撮像素子はすでにディ

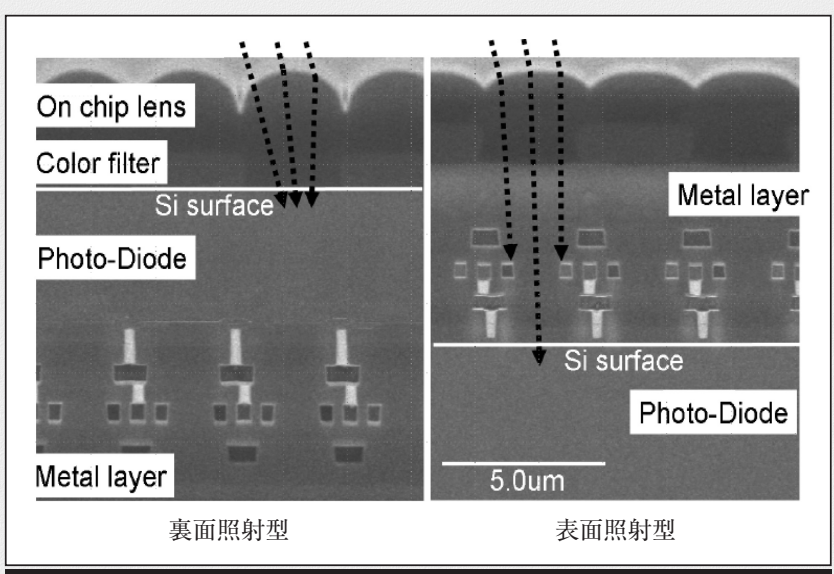

図6 裏面照射撮像素子の構造 (文献7) より引用一部追記) 


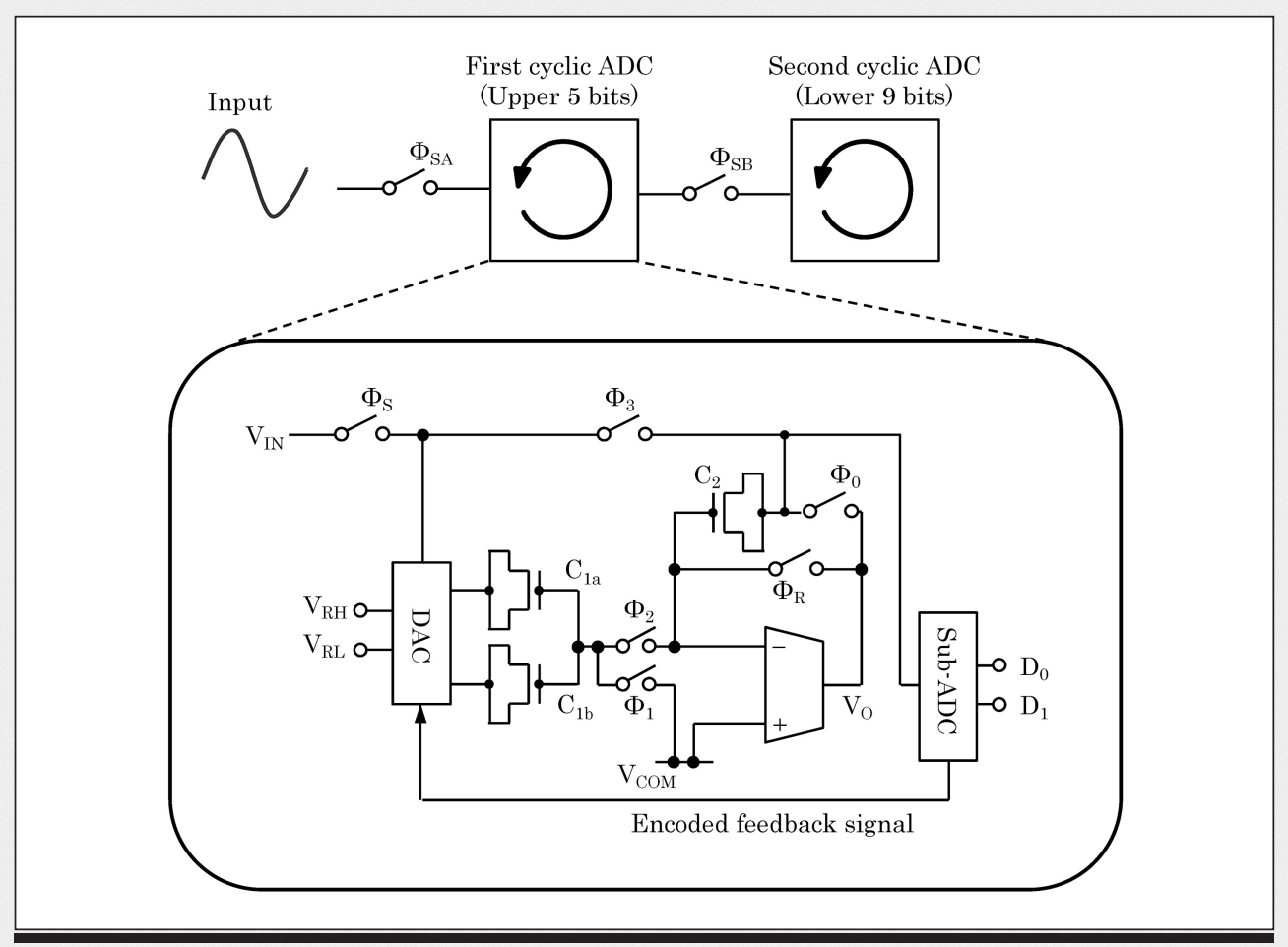

図7高速2段サイクリック型ADC

ジタルカメラやスマートフォン搭載カメラに用いられてい るが，小型化が進むUHD カメラ用撮像素子にも応用され始 めている(例えば, $2 / 3$ 型 980 万画素撮像素子 8 ) や, $2 / 3$ 型 $3,300$ 万画素撮像素子 9$)$ ).

以上のような画素の特性改善と並んで, 高速で安定に動 作する回路技術も大きく進展している. UHDカメラ用撮 像素子では, 高速で高精度に画素データを読出す必要があ るため, カラム毎に A/Dコンバータ（以下，ADCと記す） を配置し, 並列動作させる列並列 ADC 技術が用いられて いる. 例えば，4K 用撮像素子として開発された 890 万画素 撮像素子 ${ }^{10)}, 1,800$ 万画素撮像素子 ${ }^{11)}, 8 \mathrm{~K}$ 用の 3,300 万画素 撮像素子 4 , 1 億 3,300 万画素撮像素子12) などが報告されて いる.

さらに列ごとに配置する $\mathrm{ADC}$ 部の動作速度を向上し， 120 フレーム/秒の撮影を可能とする $8 \mathrm{~K}$ 用撮像素子も開発され た ${ }^{13)}$. 本撮像素子には，新たに開発された2段サイクリッ ク型 ADCが採用されている (図 7). サイクリック型 ADC を 2 段構成にし, パイプライン動作させることで, 高速動 作と低消費電力を同時に実現したものである. 本撮像素子 を用い, ハイビジョンカメラに迫る起動性や運用性を実現 した $8 \mathrm{~K}$ 単板カメラが商品化される14)15) とともに，3板式 の $8 \mathrm{~K} / 120 \mathrm{p}$ フルスペックカメラが試作されている16).

\section{3 フォーカス調整機能}

UHD の特徵である高解像度化の性能を充分発揮できるよ うに，フォーカス調整機能も検討が進められてきた. 開発 初期の $8 \mathrm{~K}$ カメではビューファインダ (以下, VFと記す) でピント位置を確認することが困難であったために，リ
モートフォーカス機能を用いて，中継車などに設置した $4 \mathrm{~K}$ モニタ上で，映像を確認しながらビデオ技術者が フォーカス調整を行っていた.

最近のUHD用カメラでは, 小型で低解像度のVFでもピ ント位置が確認しやすいように, フォーカス調整をアシス トする機能が搭載されている。例えば，VF上に映像の高 域周波数成分を着色して表示する機能や (図8 (a)), 画面 内に設けたフォーカス検出エリア内の被写体の凹凸成分を 抽出して, その積算值をレベルインジケーターに変換し, 表示する機能である(図8 (b)).

このようなフォーカス調整アシスト機能と, コントラス ト比の高い有機 $\mathrm{EL} モ$ そや小型の $4 \mathrm{~K}$ モニタを使った VF を組合せることにより，8KカメラでもカメラマンがVFを 見ながら単独でピント調整できるようになってきた。

UHDのような超高精細映像システムの撮像系では, VF やレンズ制御インタフェースなどの周辺機器の機能や性能 も, 撮影映像の画質を大きく左右する. 今後, オート フォーカス機能なども含め, UHD用カメラの操作インタ フェースでも更なる改善・改良を期待したい.

\section{4. 広色域化に対応する技術}

UHD 映像システムでは 3 原色点をスペクトル軌跡上に配 置することで, システムの色再現範囲を拡大している。こ の新しい3 原色点を使ったモニタ上の映像が，実際に人の 目で見た時と同じ色に見えるためには，撮像系での分光感 度特性が，新しい 3 原色点で定められる理想撮像特性を実 現する必要がある。 


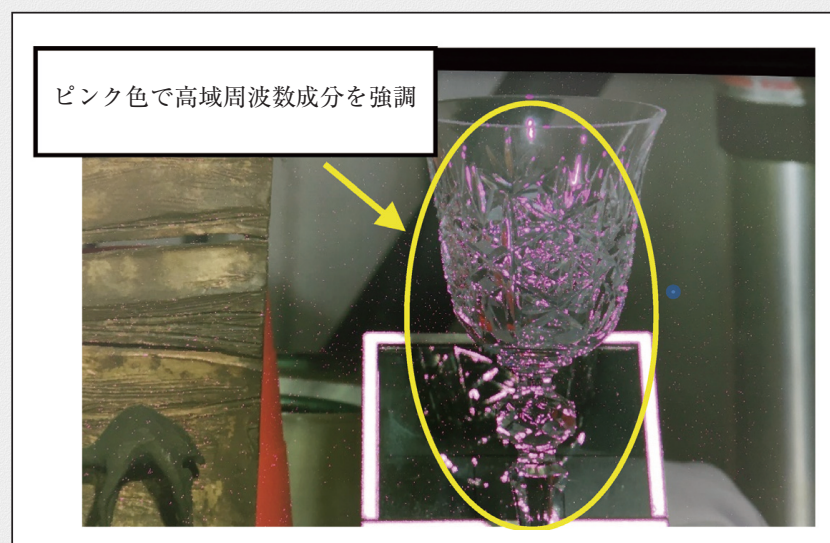

(a) 高域周波数成分の強調

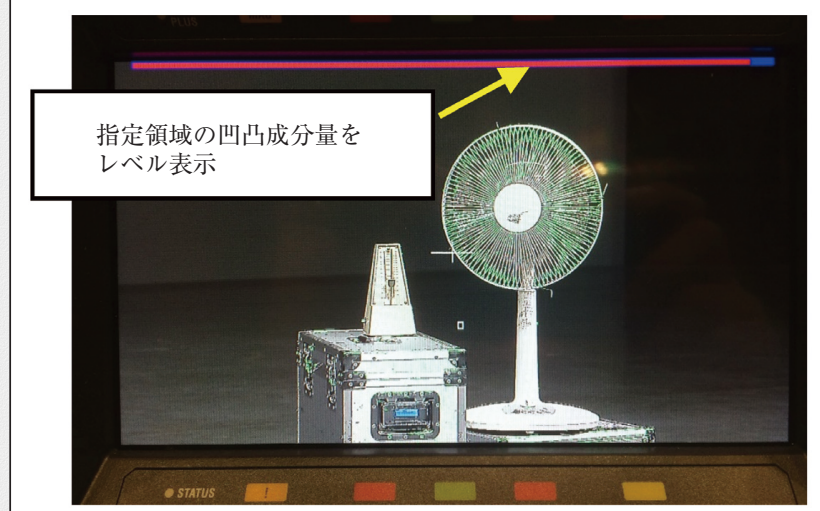

（b）凹凸成分のレベルインジゲータ

図8 ビューファインダ上のフォーカス補助機能

従来のITU-R 勧告BT.70917) で規定されている3 原色点と, UHD 用の新しい規格ITU-R勧告BT.202018)に規定されている 3 原色点で, 撮像系に求められる理想撮像特性を示す (図9).

BT.709の 3 原色点を使った理想撮像特性では, 負の成分が 大きくなることがわかる (図9 (a)). 一般にこのような負の 成分を含む理想撮像特性を実現するためには, 赤, 緑, 青 に分光するプリズムの分光感度特性を調整するとともに, リニアマトリックスなどの信号処理を併用し, 補正する方 法が用いられる. しかし, 従来の 3 原色点の場合には, 補正 係数が大きくなりすぎ, $\mathrm{S} / \mathrm{N}$ の劣化などの画質低下を招く ため, 近似的な処理しか行うことができなかった.

一方, UHD 用撮像系では, 3 原色点で囲まれる色域が広 がったために負の成分が減少している (図9(b)). そのため, 分光特性を最適化した色分解プリズムとリニアマトリック スによる補正処理により，ほぼ理想撮像特性を再現できる。 図10は, BT.2020の3 原色点に合わせて新規開発した色分解 プリズムと, 補正回路により実現したカメラの分光感度特 性である. 短波長側の赤信号の特性に多少の誤差が残るが, ほほ理想的な特性を再現できていることがわかる ${ }^{19) .}$

また，新規開発の色分解プリズムは図11に示すように， 従来プリズムの前面に設置していた視感度補正用の赤外 カット (IRカット) フィルタを不要とする構成とし, 光の

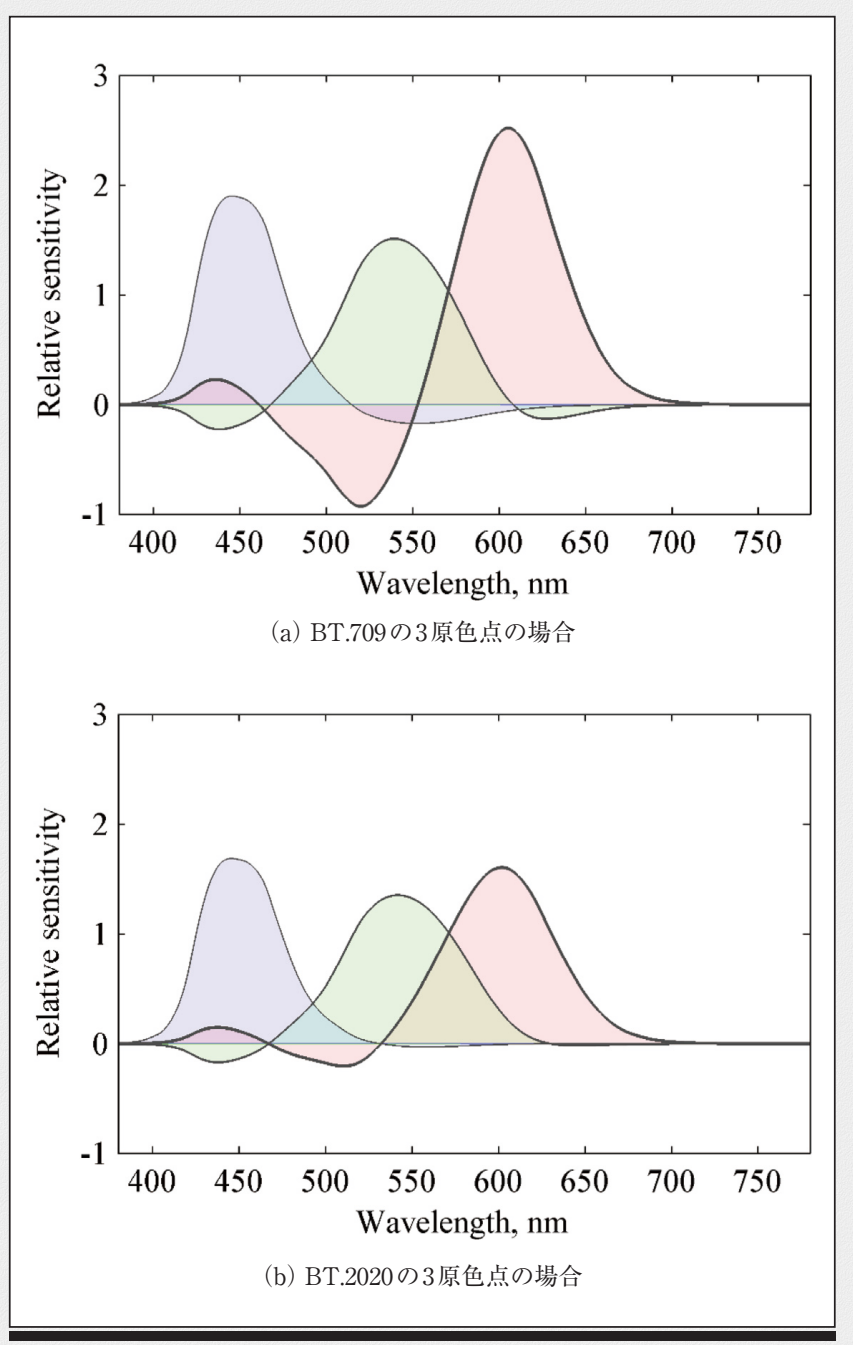

図9 理想撮像特性

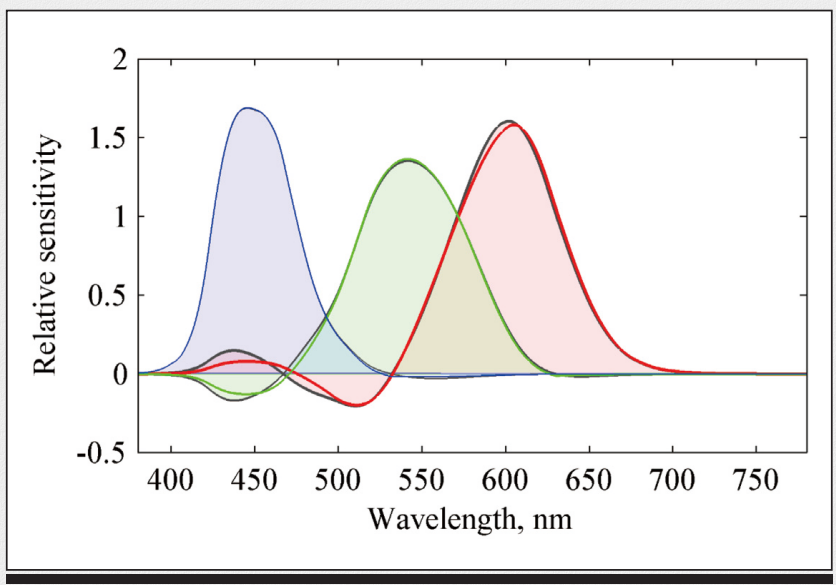

図10 新規開発した色分解プリズムとリニアマトリックス補正による 分光感度特性

利用効率を改善している.

これら光学系部分の特性改善により, 広い色域にわたっ て彩度の高い被写体を高画質で撮影可能となった。 


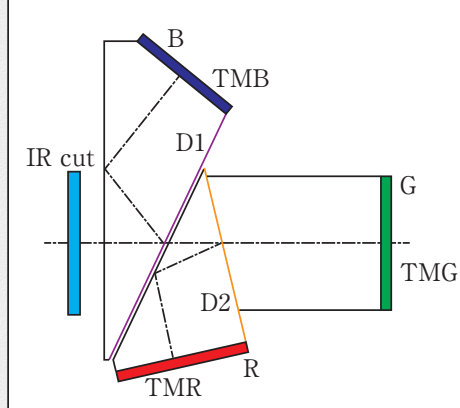

(a) 従来 (BT.709用)

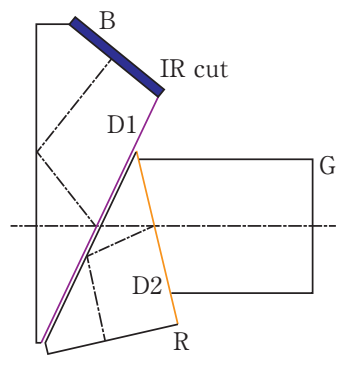

(b) 新規開発 (BT.2020用)
図11 色分解プリズムの構成 (文献 19) より引用)

(a) R， G，Bの射出ロにトリミングフィルタ（TMR，TMG，TMB）を 設け，プリズム前面にIRカットフィルタを配置，(b) 反射面 (D1，D2) の特性を調整し，IRカットフィルタをB射出口のみに配置することで 光の利用効率を改善.

\section{5. 高ダイナミックレンジ化に対応する技術}

高ダイナミックレンジ (HDR: High Dynamic Range) 映像 の代表的な方式として Hybrid Log-Gamma (HLG) 方式と, Perceptual Quantization (PQ) 方式が挙げられる20).ここで は，撮像系におけるHDR化として，従来の標準ダイナミッ クレンジ (SDR: Standard Dynamic Range) モードと, HDR 映像を撮影するHLGモードの実装例を紹介する。

従来のSDR モードでは撮像素子の性能を見極め, 撮像素 子出力信号におけるピーク白 (100\%白) を決定し, BT.709 に規定された撮像側の光一電気伝達関数 (Opto-Electronic Transfer Function: OETF) を用いて電気信号に変換してい る.SDRモードでのOETFの一例を示す（図12：SDRモー ド). 撮像素子出力信号の飽和信号の約 $1 / 6$ のレベルをピー ク白と規定し，0から 1/6までのレベルをOETFに沿ってカ
メラ出力信号に変換している. カメラ出力信号では $10 \%$ 程 度のヘッドルームを有し，ピーク白を超えるスーパー白の 領域を確保している.ここでは, 撮像素子出力信号の $1 / 6$ から 1 までの範囲を, カメラシステム出力のスーパー白の 領域 (カメラ出力 1 ～1.1) に圧縮する例を示している.

一方, HLGモードでは, 高輝度部分も含めて OETFに規 定されているため, SDRモードに比べてょり高いレベルの 撮像素子出力をピーク白に設定する.ここでは飽和信号レ ベルをピーク白として HLG方式の OETFを用い, 電気信 号に変換した例を示す (図 12 : HLG モード). SDR と同等 の 0.5 乗べき関数の OETFは，撮像素子の飽和レベルの約 $1 / 12$ までのレベル，それ以上のところは対数関数での OETF となる (講座第 1 回参照 $\left.{ }^{21)}\right)$. SDR モードではスー パー白領域に圧縮されていた信号が, HLGモードでは 0.7 〜 1 の範囲で伝送されるため, 撮像系から高輝度領域の情 報が，より忠実に後段に伝送できることがわかる.さらに HLGモードでもSDR モード同様に，スーパー白の部分を 利用して, より高ダイナミックレンジの映像情報を出力で きるカメラもある。

HDR撮影において撮像系に求められるのは, 上記のよう な高輝度領域の再現性とともに, 中低輝度領域における $\mathrm{S} / \mathrm{N}$ の確保である. 従来 SDR モードと同じべき関数の OETF となる領域はHLG モードにおいては, 飽和信号の約 $1 / 12$ までと従来の約半分の信号レベルとなっている. した がって，この範囲の映像が HDR モニタ上でSDR と同様の 見え方となるためには $6 \mathrm{~dB}$ 程度の $\mathrm{S} / \mathrm{N}$ 改善が必要となる. また, 取り扱う信号電荷も少なくなることから, 入射光に よる光ショットノイズの抑圧も大きな課題である.

現在, 更なる高画質HDR 映像の撮影に向け, 撮像素子側 ではノイズレベルの低減による $\mathrm{S} / \mathrm{N}$ 改善や, 飽和信号電荷

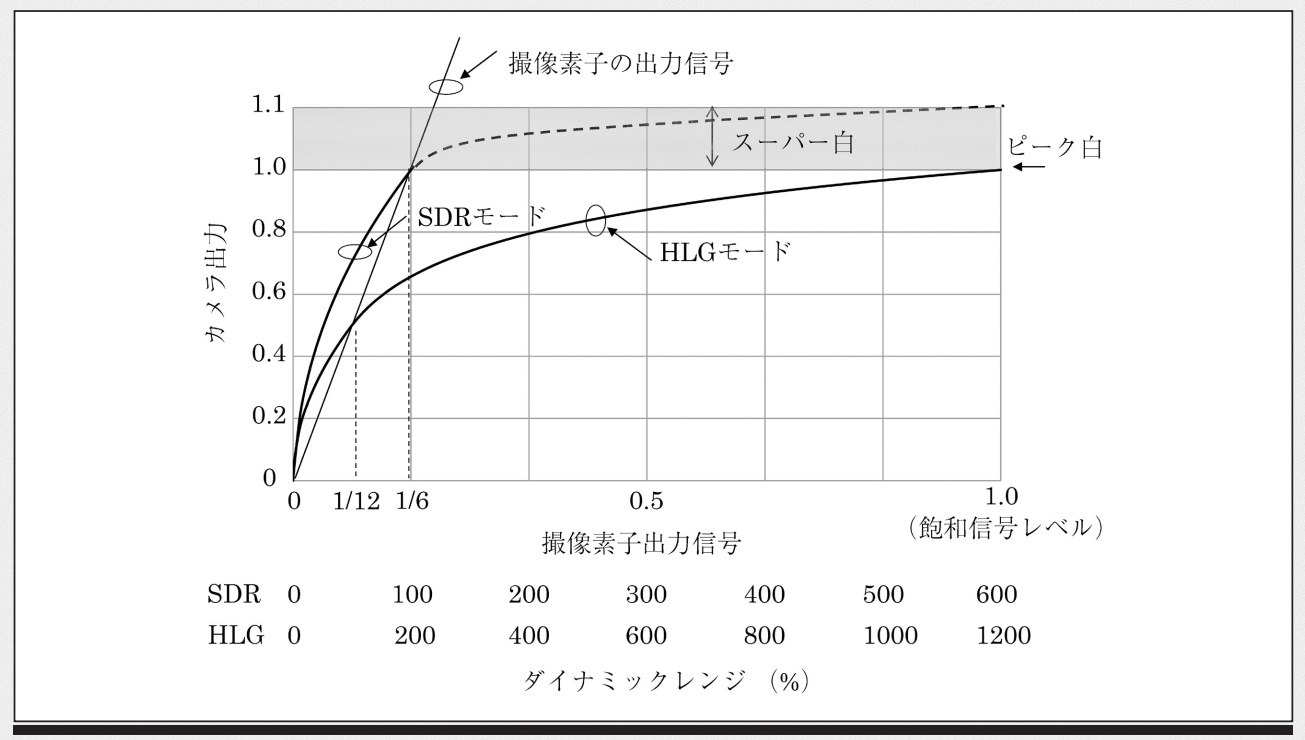

図12 カメラ出力信号における OETF適用例（SDRモードとHLGモード） 
量の拡大など, ダイナミックレンジ拡大に向けた検討が進 んでいる. 先に紹介した裏面照射型の構造のほかに, 光電 変換膜を用いた積層膜型撮像素子 22) や, 3 次元構造撮像素 子23) も検討されている. また, カメラシステム内の信号処 理では, 確率統計技術を使った処理など, より柔軟で適応 的なノイズ抑圧法の開発が進められている.

\section{6. むすび}

UHD は, 広色域化やHDRなど, 従来の映像システムに はない新しい仕様が盛り込まれており，より臨場感や実物 感ある映像を提供できるシステムである. 本稿では, この ような高画質なUHD映像を撮影するための, 撮像系にお ける特徴的な技術を解説した。

先述したように，この 10 年余の撮像系に係る技術進歩は 目を見張るものがある. 撮像素子をはじめ, 光学系, 信号 処理回路, 操作インタフェースなど, それぞれの分野の技 術者が連携して高画質化に向けて研究開発に取組んだ成果 である。

すでに幅広い制作機材が開発され，それらを用いてUHD 映像の特徵を活かした番組作りが盛んに行われている. カ メラを含めた高画質なUHD機材が運用面, コスト面から もハイビジョン機材並みの身近なものになるのも, そう遠 くないように思われる.

(2017年2月 23 日受付)

\section{〔文 献〕}

1) Kanazawa et al.: "Ultrahigh-definition Video System with 4000 Scaninng Lines", Proc. IBC, pp.321-329 (2003)

2）三谷公二, 島本洋, 藤田欣裕：“4板撮像方式を用いた 2000 ライン動 画撮像装置”，テレビ誌，50，2，pp.295-301（1995）

3）西田幸博：“スーパーハイビジョンの映像パラメータと国際標準化”, NHK技 R\&D，137，pp.10-19（Jan. 2013）

4) S. Huang, et al.: "A 2.5 inch, 33Mpixel, 60 fps CMOS Image Sensor for UHDTV Application", Proceeding of 2009 International Image Sensor Workshop (June 22-28, 2009)

5）ARIB技術資料 TR-B37：“超高精細度テレビジョン方式カメラ・レ ンズ機器の互換接続”

6）山下ほか：“スーパーハイビジョン・フル解像度カメラシステム”, NHK技研R\&D，122 (July 2010)

7）丸山ほか：“裹面照射型 CMOSイメージセンサ”，映情学技報，30， 25, pp.25-28 (Mar. 2006)

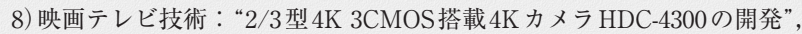
pp.48-50 (Nov. 2016)
9) T. Arai et al.: "A $1.1 \mu \mathrm{m}$ 33Mpixel 240fps 3D-Stacked CMOS Image Sensor with 3-Stage Cyclic-Based Analog-to-Digital Converters", 2016 ISSCC Dig. Tech. Papers, pp.126-127 (Feb. 2016)

10)S. Matsuo, et al.: "8.9-Megapixel Video Image Sensor with 14-b Column-Parallel SA-ADC", IEEE Transaction on Electron Devices, 56, 11 (Nov. 2009)

11) T. Toyama, et al: "A 17.7Mpixel 120fps CMOS image sensor with 34.8Gbps readout", in Proc. ISSCC Dig. Tech. Papers, pp.420-422 (Feb. 2011)

12) R. Funatsu, et al.: "A 133-Mpixel 60-fps CMOS Image Sensor with 32Column Shared High-Speed Column Parallel SAR-ADCs", 2015 ISSCC Dig. Tech. Papers, 6.2 (Feb. 2015)

13) T. Yasue, et al.: "A 14-bit, 33-Mpixel, 120-fps Image Sensor with DMOS Capacitors in 90-nm/65-nm CMOS", Proc. 2015 Int. Image Sensor Workshop, 7.03, pp.200-203 (2015)

14) http://hitachi-kokusai.co.jp/news/2015/news150406.html

15) http://www.ikegami.co.jp/archives/menul/shk-810

16) K. Kitamura, et al.: "Full-specification 8K Super Hi-Vision camera", 1st International Conference on Advanced Imaging (ICAI 2015), T304-02, pp.366-369 (2015)

17) ITU-R, Recommendation ITU-R BT.709-6: "Parameter values for the HDTV standards for production and international programme exchange" (1990)

18) ITU-R, Recommendation ITU-R BT.2020-2: "Parameter values for ultra-high definition television systems for production and international programme exchange" (2012)

19)K. Masaoka et al.: "Designing Camera Spectral Sensitivities for UHDTV", SMPTE Motion Imaging Journal, pp.26-32 (Nov. /Dec. 2014)

20) ITU-R, Recommendation BT.2100-0: "Image parameter values for high dynamic range television for use in production and international programme exchange" (2016)

21) 西田幸博：“講座：UHDを支える映像の高画質化技術（第 1 回） UHD 映像の概要”，映情学誌， 71，2，pp.216（Mar. 2017）

22)村上ほか：“有機CMOSイメージセンサ〜 120dB ワイドダイナミッ クレンジ, 光電変換制御グローバルシャッタ〜”, 映情学技報, 40 , 12, pp.53-56 (Mar. 2016)

23) M. Goto, et al.: "3-D Silicon-on-Insulator Integrated Circuits with NFET and PFET on Separate Layers Using Au/SiO2 Hybrid Bonding", IEEE Transactions on Electron Devices, 61, 8, pp.2886$2892(2014)$

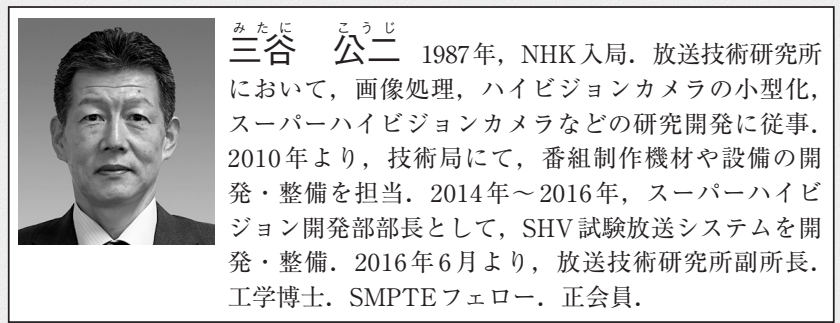

